\author{
Karol Pachnik, Ph.D. a)* $^{\star}$ \\ a) Siedlce University of Natural Sciences and Humanities, Faculty of Economic and Legal Sciences / \\ Uniwersytet Przyrodniczo-Humanistyczny w Siedlcach, Wydział Nauk Ekonomicznych i Prawnych \\ *Corresponding author / Autor korespondencyjny: karolpachnik@uph.edu.pl
}

\title{
Firefighting Expert Witnesses and Their Role in the Safety System
}

\section{Biegli z zakresu pożarnictwa i ich rola w systemie bezpieczeństwa}

\begin{abstract}
Objective: The aim of the article is to present and characterise the professionals who - thanks to their specialised knowledge - are part of the safety system Introduction: Fire prevention and identifying the causes of fires are key issues in the internal safety system. The authorities are not capable of executing their powers without support from professionals who have the necessary qualifications. In the Polish legal system, there are a number of professionals who have specialised knowledge (expertise), which is the reason for engaging them in the process of making judgments and decisions by judicial and administrative authorities. Such tasks are mostly associated with the profession of a (court) expert witness. With regard to firefighting, there are also fire-safety expert witnesses. There are no complex legal regulations concerning such experts. The level of competence needed for obtaining the status of an expert witness or other firefighting expert is regulated in several different legal acts. Only a comprehensive study of such acts could help explain the role of professionals with specialised knowledge within the safety system.

Methodology: This study is based on a theoretical analysis of the legal system and a comparison of the solutions adopted in specific acts with their interpretations in court decisions and relevant literature.

Conclusions: It has been found that, when exercising public powers concerning fire prevention, there is a legal requirement to use the assistance provided by other professionals with specialised knowledge and firefighting expert status. In addition, during administrative or court proceedings and investigations there is a legal obligation to only use (court) expert witness assistance. Those professionals need to meet specific criteria to be able to perform their functions. The primary requirement is that they have the necessary qualifications (knowledge and experience) to issue expert opinions. The support of expert witnesses is also desirable in the winding-up proceedings of insurance companies concerning the payment of compensation for damages resulting from fire. However, even the most renowned expert witnesses cannot make final decisions for the authority that seeks their assistance, and their opinions are never binding.
\end{abstract}

Keywords: expert witness, safety, fire, emergency

Type of article: review article

Received: 30.01.2019; Reviewed: 15.02.2019; Accepted: 28.06.2019;

Author's ORCID ID: https://orcid.org/0000-0003-2311-8522

Please cite as: SFT Vol. 53 Issue 1, 2019, pp. 162-172, https://doi.org/10.12845/sft.53.1.2019.10;

This is an open access article under the CC BY-SA 4.0 license (https://creativecommons.org/licenses/by-sa/4.0/).

\section{ABSTRAKT}

Cel: Celem artykułu jest przedstawienie i scharakteryzowanie podmiotów, które - będąc w posiadaniu wiadomości specjalnych - stanowią element systemu bezpieczeństwa.

Wprowadzenie: Prewencja oraz ustalanie przyczyn pożarów to istotne zagadnienia dla bezpieczeństwa wewnętrznego. Aby organy państwa mogły sprawnie realizować swoje kompetencje w tym zakresie, potrzebują wsparcia w zakresie wiedzy specjalistycznej. W polskim systemie prawnym występuje grupa podmiotów, które posiadają wiadomości specjalne, użyteczne w postępowaniach prowadzonych przez organy administracji, organy ścigania czy sądy. Są nimi najczęściej biegli sądowi. W kręgu problematyki pożarnictwa pojawić się mogą jeszcze rzeczoznawcy do spraw zabezpieczeń przeciwpożarowych. Nie ma jednej kompleksowej regulacji prawnej dotyczącej takich podmiotów. O tym, jakie kompetencje wiążą się z nabyciem roli biegłego czy rzeczoznawcy do spraw zabezpieczeń przeciwpożarowych, decydują regulacje zawarte w wielu różnych ustawach. Dopiero ich kompleksowe zbadanie może dać odpowiedź na pytanie, jaką rolę w systemie bezpieczeństwa odgrywają podmioty będące w posiadaniu wiadomości specjalnych.

Metodologia: Badania przeprowadzono poprzez analizę obowiązującego stanu prawnego oraz porównanie rozwiązań zawartych w poszczególnych ustawach z ich interpretacją w orzecznictwie sądowym i piśmiennictwie.

Wnioski: Dostrzeżono prawny obowiązek korzystania przez organy państwa z wiadomości specjalnych, którymi dysponują grupy podmiotów funkcjonujących w obszarze bezpieczeństwa pożarowego (takich jak biegli sądowi z zakresu pożarnictwa czy rzeczoznawcy do spraw zabezpieczeń przeciwpożarowych). Podmioty te muszą spełniać określone kryteria, które pozwalają im na wykonywanie swoich funkcji. Podstawowym kryterium jest posiadanie 
wysokich kwalifikacji (wiedzy i doświadczenia) pozwalających na wydanie opinii. Pomoc biegłych jest pożądana także w postępowaniach prowadzonych przez ubezpieczycieli, głównie w zakresie ustalenia odpowiedzialności TU w związku z zaistniałą szkodą pożarową. Odpowiedzialność ta może być ograniczona lub - w skrajnych przypadkach nieprzestrzegania przez ubezpieczonego obowiązujących przypisów dotyczących bezpieczeństwa pożarowego lub innych wskazań wynikających np. z zawartej umowy ubezpieczenia - TU może być z niej nawet zwolnione.

Słowa kluczowe: biegli, bezpieczeństwo, pożary, zagrożenie

Typ artykułu: artykuł przeglądowy

Przyjęty: 30.01.2019; Zrecenzowany: 15.02.2019; Zatwierdzony: 28.06.2019;

Identyfikator ORCID autora: https://orcid.org/0000-0003-2311-8522

Proszę cytować: SFT Vol. 53 Issue 1, 2019, pp. 162-172, https://doi.org/10.12845/sft.53.1.2019.10;

Artykuł udostępniany na licencji CC BY-SA 4.0 (https://creativecommons.org/licenses/by-sa/4.0/).

\section{Introduction}

According to S. Wieteska, "the issue of fires has been of interest to economic, social and technical scientists for many years, and fire rescue has occupied a major position within the public safety organisational structures" [1]. The assurance of safety begins with preventive measures [2, p. 98]. M. Wolanin has stressed that "in order to ensure the safety of a given facility or system, it is necessary to counteract threats. When analysing safety problems (in any facility), two fundamental aspects should be taken into account, i.e. threat and safety" [3, p. 981].

A review of various scientific publications and reports shows a number of irregularities which reflect a rather poor culture of fire safety among building owners and administrators in Poland. As argued by P. Janik, "while there is some understanding of the difficulties, mainly financial, related to eliminating certain technical conditions posing threat to people in the buildings erected many years ago, and not conforming to the currently acceptable safety standards, there is no justification for negligence in ensuring that escape routes are unobstructed at all times, clamming them with flammable materials, failing to perform regular inspections of the systems and equipment in use, including fire protection systems, or the lack of developed and implemented fire protection guidelines regarding, inter alia, evacuation. What also appears striking is that comparable levels of fire safety negligence are found regardless of the degree of risk in various facilities. It appears that the implementation of more rigorous fire safety procedures is not even fostered by the use of technological systems within the facility, often containing materials which might create a fire hazard" [4, p. 57].

Threats can be eliminated, and the desirable level of safety achieved, by developing an adequate approach to fire prevention, building on the mechanisms established on the basis of the applicable law.

D. Witczak has stressed that the pace of civilisation change and the necessity of ensuring fire safety both create the need to continually adjust legal regulations to the new conditions of daily life [5, p. 129]. In the area of firefighting, the Act of 21 August

\section{Wprowadzenie}

Zdaniem S. Wieteski „problematyka pożarów jest od bardzo wielu lat przedmiotem zainteresowania nauk ekonomicznych, społecznych i technicznych, a ratownictwo pożarowe zajmuje ważne miejsce w strukturach organizacyjnych bezpieczeństwa publicznego" [1]. Zapewnienie bezpieczeństwa rozpoczyna się od działań prewencyjnych [2, s. 98]. M. Wolanin podkreśla, że „aby zapewnić bezpieczeństwo dowolnego obiektu lub innego systemu, należy przeciwdziałać zagrożeniom. Analizując problemy bezpieczeństwa (dowolnego obiektu), powinno się mieć na uwadze dwa fundamentalne pojęcia - zagrożenie i bezpieczeństwo" [3, s. 981].

Analizując treści raportach i publikacjach naukowych, dostrzega się szereg nieprawidłowości, świadczących o dość niskiej kulturze bezpieczeństwa pożarowego właścicieli i zarządców obiektów w Polsce. P. Janik wskazuje, że „o ile można zrozumieć trudności, głównie finansowe, związane z usunięciem technicznych warunków zagrożenia życia ludzi w budynkach wybudowanych wiele lat temu, niezgodnie $z$ akceptowalnymi obecnie standardami bezpieczeństwa, o tyle niedbałość o zapewnienie drożności dróg ewakuacyjnych, składowanie na nich materiałów palnych, niezapewnianie przeglądów okresowych instalacji i urządzeń użytkowych oraz przeciwpożarowych czy wreszcie brak opracowania i wdrożenia instrukcji przeciwpożarowych, np. w zakresie ewakuacji, nie znajdują już żadnego usprawiedliwienia. Charakterystyczne jest również to, że porównywalny stopień zaniedbań w zakresie bezpieczeństwa pożarowego jest stwierdzany niezależnie od skali zagrożenia występującego w danym obiekcie. Stawia się tezę, że do wdrożenia bardziej rygorystycznych procedur bezpieczeństwa pożarowego nie skłania nawet fakt użytkowania w obiekcie instalacji technologicznych, często z materiałami niebezpiecznymi pożarowo" [4, s. 57].

Eliminacja zagrożenia, a tym samym osiągnięcie pożądanego poziomu bezpieczeństwa, osiągana jest przez tworzenie modelu postępowania w ramach prewencji przeciwpożarowej. Model zaś powstaje w oparciu o mechanizmy tworzone na podstawie obowiązującego prawa. 
1991 on Fire Protection (consolidated text, Journal of Laws of 2018, item 620) constitutes the principal legal act.

Based on the definition arising from that Act, fire protection means taking measures aimed at protecting life, health, property and the environment against fires, natural disasters or other local hazards, by:

1) preventing the occurrence and spread of a fire, natural disaster or any other local hazard;

2) providing the necessary manpower and means of combating a fire, natural disaster or any other local hazard;

3) conducting rescue operations.

The occurrence and spread of a fire can be prevented, inter alia, by providing the necessary conditions for technical protection of real and personal property.

Within the national legal system there is a number of entities, which, thanks to their specialised knowledge, are expected to make informed judgements on specific topics. Although experts' judgements are not always considered opinions [6, p. 4], they often exert a tangible impact on conducted proceedings.

\section{Fire-safety expert witnesses}

As regards the issue of fire protection, a major role in preventing the occurrence of fires is played by fire-safety expert witnesses (see Article 2 (1) of the Act of 21 August 1991 on Fire Protection).

Under the binding regulations, a fire-safety expert witnesses is a person holding the necessary qualifications to work in the profession of a "firefighting engineer," or having the scientific degree of "Engineer" or "Master of Science in Engineering," who has undergone professional training and passed the necessary examination. The examination confirming successful completion of professional training covers the knowledge of the applicable legal regulations and technical knowledge of fire protection, as well as the ability to meet the relevant requirements and select the adequate fire safety measures.

Fire-safety expert witnesses are allowed to review construction designs for buildings and fire protection equipment designs, to issue expert opinions on technical issues and other technical studies regarding fire protection, and to provide fire protection services which include preventing the occurrence and spread of fires.

There are also several requirements which fire-safety expert witnesses must satisfy, including the obligation to independently improve their professional qualifications. They are, in particular, expected to:

1) prepare and present reports at scientific or technical congresses, meetings, conferences or symposia;

2) author or co-author books, articles or translations;
D. Witczak akcentuje, że tempo zmian cywilizacyjnych, a także konieczność zapewnienia bezpieczeństwa pożarowego wymusza niejako potrzebę ciągłego dostosowywania przepisów prawnych do realiów życia codziennego [5, s. 129]. W zakresie związanym z pożarnictwem podstawowym aktem prawnym jest ustawa z dnia 21 sierpnia 1991 r. o ochronie przeciwpożarowej (t.j. Dz.U. z 2018 r. poz. 620).

Zgodnie z przyjętą definicją wynikająca, ze wskazanej ustawy ochrona przeciwpożarowa polega na realizacji przedsięwzięć mających na celu ochronę życia, zdrowia, mienia lub środowiska przed pożarem, klęską żywiołową lub innym miejscowym zagrożeniem poprzez:

1) zapobieganie powstawaniu i rozprzestrzenianiu się pożaru, klęski żywiołowej lub innego miejscowego zagrożenia;

2) zapewnienie sił i środków do zwalczania pożaru, klęski żywiołowej lub innego miejscowego zagrożenia;

3) prowadzenie działań ratowniczych.

Zapobieżenie powstawaniu i rozprzestrzenianiu się pożaru to m.in. zapewnienie koniecznych warunków ochrony technicznej nieruchomościom i ruchomościom.

W krajowym systemie prawnym istnieje szereg podmiotów, które dzięki posiadaniu wiadomości specjalnych, mają w zamierzeniu kompetentnie wypowiadać się o określonych dziedzinach. Chociaż nie zawsze wypowiedź ekspercka nosi nazwę opinii [6, s. 4], często podmioty te w sposób faktyczny wpływają na kierunek toczącego się postępowania.

\section{Rzeczoznawcy do spraw zabezpieczeń przeciwpożarowych}

W odniesieniu do zagadnień ochrony przeciwpożarowej istotną rolę w zapobieganiu powstawaniu pożarów odgrywają rzeczoznawcy do spraw zabezpieczeń przeciwpożarowych - por. art. 2 pkt 1 ustawy z dnia 21 sierpnia 1991 r. o ochronie przeciwpożarowej.

Zgodnie z obowiązującymi przepisami rzeczoznawcą do spraw zabezpieczeń przeciwpożarowych może być osoba, która posiada kwalifikacje wymagane do wykonywania zawodu „inżynier pożarnictwa" lub posiada tytuł zawodowy „inżynier” lub "magister inżynier" oraz przygotowanie zawodowe potwierdzone egzaminem złożonym z wynikiem pozytywnym. Egzamin potwierdzający przygotowanie zawodowe obejmuje znajomość przepisów prawa i zasad wiedzy technicznej dotyczących ochrony przeciwpożarowej, a także umiejętność stosowania zawartych w nich wymagań i doboru zabezpieczeń przeciwpożarowych odpowiednio do tych wymagań.

Rzeczoznawca do spraw zabezpieczeń przeciwpożarowych jest uprawniony do uzgadniania projektów budowlanych obiektów budowlanych i projektów urządzeń przeciwpożarowych, sporządzania ekspertyz technicznych i innych opracowań technicznych z zakresu ochrony przeciwpożarowej oraz wykonywania czynności z zakresu ochrony przeciwpożarowej, w tym polegających na zapobieganiu powstawaniu i rozprzestrzenianiu się pożaru.

Rzeczoznawcom do spraw zabezpieczeń przeciwpożarowych stawianych jest też szereg wymagań, miedzy innymi obowiązek 
3) participate in scientific or technical congresses, meetings, conferences or symposia;

4) participate in workshops and other forms of training;

5) participate in online education programmes focusing on the knowledge and skills related to fire protection.

The activities of fire-safety expert witnesses are supervised by the Chief Commanding Officer of the State Fire Service, through Regional Commanding Officers of the State Fire Service. The supervision covers such activities as

1) reviewing construction designs and fire protection equipment designs;

2) issuing expert opinions on technical issues or judgements referred to in fire protection regulations;

3) satisfying such requirements as:

- notifying the Regional Commanding Officer of the State Fire Service, appropriate for the investment location, of reviewing a construction design for a building, within 14 days of such a review;

- notifying the Chief Commanding Officer and the Regional Commanding Officers of the State Fire Service, appropriate for the new and previous places of residence, of changing the place of residence, within 30 days of such a change,

- keeping records of the reviewed construction designs for buildings, for a period of 5 years, along with copies of notifications regarding such reviews and evidence that they have been sent.

As they exercise their supervisory powers, the Chief Commanding Officer of the State Fire Service and Regional Commanding Officers of the State Fire Service are allowed to conduct preliminary investigations.

Considering the above, these entities can be assumed to use their expertise in performing fire safety services in the field of fire prevention. samodzielnego podnoszenia kwalifikacji zawodowych. Obejmuje on przede wszystkim takie aktywności jak:

1) przygotowanie iwygłoszenie referatu na kongresie, zjeździe, konferencji lub sympozjum naukowym lub technicznym;

2) opublikowanie jako autor lub współautor książki, artykułu lub tłumaczenia;

3) udział w kongresach, zjazdach, konferencjach lub sympozjach naukowych lub technicznych;

4) udział w warsztatach szkoleniowych $i$ innych formach szkoleń;

5) udział $w$ internetowych programach edukacyjnych - w zakresie wiedzy i umiejętności dotyczących ochrony przeciwpożarowej.

Nadzór nad działalnością rzeczoznawców sprawuje Komendant Główny Państwowej Straży Pożarnej przy pomocy komendantów wojewódzkich Państwowej Straży Pożarnej. Jest on sprawowany w zakresie:

1) uzgadniania przez rzeczoznawców projektów budowlanych oraz projektów urządzeń przeciwpożarowych;

2) wykonywania ekspertyz technicznych lub opinii, o których mowa w przepisach dotyczących ochrony przeciwpożarowej;

3) wywiązywania się z obowiązków:

- przesyłania zawiadomienia o uzgodnieniu projektu budowlanego obiektu budowlanego komendantowi wojewódzkiemu Państwowej Straży Pożarnej właściwemu dla miejsca lokalizacji inwestycji w terminie $14 \mathrm{dni}$ od dnia uzgodnienia dokumentu;

- zawiadamiania KG PSP i komendantów wojewódzkich PSP właściwych ze względu na nowe i poprzednie miejsce zamieszkania w terminie 30 dni od dnia zmiany miejsca zamieszkania,

- prowadzenia i przechowywania przez okres 5 lat ewidencji uzgodnionych projektów budowlanych obiektów budowlanych oraz kopii zawiadomień o uzgodnieniu tych projektów, wraz z dowodami ich wysłania.

W ramach sprawowania nadzoru Komendant Główny Państwowej Straży Pożarnej lub komendant wojewódzki Państwowej Straży Pożarnej mogą przeprowadzać postępowanie wyjaśniające.

Wobec powyższego należy przyjąć, że opisywane podmioty wykorzystują wiedzę specjalistyczną, świadcząc usługi na rzecz bezpieczeństwa pożarowego w zakresie prewencji pożarowej.

\section{Biegli i ich rola}

P. Guzewski zauważył, że podstawą współczesnego procesu ustalania przyczyny pożaru jest usystematyzowane podejście oparte na analizie naukowej [9, s. 907]. Na tym etapie konieczne jest korzystanie z wiedzy osób mających wiadomości specjalne. Jeżeli takie osoby powoływane są do ustalania przyczyn pożarów w procesach sądowych albo innych postępowaniach urzędowych, występują one jako biegli. W Polsce nie ma jednego aktu prawnego regulującego kompleksowo problematykę biegłych. Istnieją jedynie regulacje szczątkowe w ustawach procesowych. Mimo operowania podobnym nazewnictwem (biegli, biegli sądoprocedural acts. Despite using similar nomenclatures (expert 
witnesses, court experts), various regulations significantly differ from one another. Nevertheless, this is not of fundamental significance to this article.

Generally speaking, expert witnesses (see more [10]) are people having specialised knowledge (i.e. expertise in a given field), extending beyond general knowledge. They can be entered on the list kept by the chairperson of the local court, in which case they are referred to as court experts. However, not being entered on such a list does not disqualify a person from acting as an expert witness, as the list only serves informative purposes and facilitates finding specialists in a given field. Entry on the list is a pure formality. The candidate must prove that he/she holds the necessary qualifications by confirming their education, professional experience, or membership of scientific or professional associations. Their knowledge, however, is not formally verified.

In any case - and in particular when there are no expert witnesses in a given field, or they refuse to issue an expert opinion, or obtaining their opinion would take too much time - the court or public prosecutor can request such an opinion from a person who have specialised knowledge but has not been entered on the list of court experts. In legal doctrine, such a person is referred to as an ad hoc expert.

As regards administrative proceedings, court experts do not appear at all. Administration authorities do not keep any list of expert witnesses but always appoint the so-called ad hoc experts. An example of such proceedings is a situation in which the State Fire Service authorities issue a decision invalidating a reviewed construction design in the course of the investment process, i.e. from the moment of obtaining a decision on granting the construction permit to the investment completion and issuing the occupancy permit [11].

The assistance of an expert witness is also recommended whenever determining the facts in a given case requires specialised knowledge - even when the authority itself has such knowledge. This requirement is connected with the need to gather objective evidence, as any determinations made arbitrarily by the competent authorities or courts, based on their own expertise, could meet with justified criticism as regards the integrity of the proceedings.

Expert witnesses' specialised knowledge is used in the circumstances where fire prevention has failed. The accurate determinations made by expert witnesses make it possible to verify the fire safety standards from a broad perspective.

When identifying the cases of fires, expert witnesses are usually engaged in connection with criminal proceedings. They are also appointed in civil cases, inter alia, when the payment of damages is at play. In such cases, they determine whether specific requirements have been met, taking into account the fact that the insured party, under the general terms and conditions of insurance, is required to comply with the generally binding regulations (including construction law, as well as provisions regarding fire protection, operation and maintenance of buildings and structures, construction and operation of technical equipment, technical supervision of equipment, and specific obligations stipulated in the insurance agreement (see [12]). wi) poszczególne regulacje znacząco różnią się od siebie. Nie ma to jednak pierwszorzędnego znaczenia dla niniejszego artykułu.

Uogólniając, można stwierdzić (szerzej por. [10]), że biegłym jest osoba posiadająca wiadomości specjalne (czyli szczególną specjalistyczną wiedzę z danej dziedziny) wykraczającą poza wiedzę ogólną. Biegły może być wpisany na listę prowadzoną przez prezesa właściwego terytorialnie sądu okręgowego. Wówczas nazywa się go biegłym sądowym. Brak wpisu na listę nie pozbawia prawa do występowania w charakterze biegłego. Wspomniana lista pełni funkcję informacyjną, pozwalającą na szybkie odnalezienie specjalistów z danej dziedziny. Wpis na listę jest czynnością czysto formalną. Kandydat musi wylegitymować się posiadaniem odpowiednich kwalifikacji, co czyni poprzez wskazanie swojego wykształcenia, doświadczenia zawodowego czy przynależności do towarzystw naukowych bądź zawodowych. Jego wiedza nie jest weryfikowana.

Zawsze - a szczególnie w przypadkach braku biegłych o danej specjalności, uzasadnionej odmowy sporządzenia przez biegłego opinii czy w sytuacji nadmiernie długiego terminu oczekiwania - sąd czy prokurator może powołać do wydania opinii osobę, która posiada wiadomości specjalne, a nie figuruje na liście biegłych sądowych. Taką osobę $\mathrm{w}$ doktrynie nazywa się biegłym ad hoc.

Natomiast w postępowaniach przed organami administracji nie występują w ogóle biegli sądowi. Organy administracji nie tworzą listy biegłych. Zawsze powołują tzw. biegłych ad hoc. Przykładem takiego postępowania przed organami administracji jest sytuacja, w której organy Państwowej Straży Pożarnej mogą wydać postanowienie unieważniające uzgodnienie projektu budowlanego w czasie trwania całego procesu inwestycyjnego, a więc od momentu uzyskania decyzji o pozwoleniu na budowę do czasu zakończenia inwestycji i uzyskania pozwolenia na użytkowanie [11].

Skorzystanie z pomocy biegłego jest wskazane zawsze, kiedy w sprawie konieczne są ustalenia z wykorzystaniem wiadomości specjalnych - nawet wtedy, gdy organ takie wiadomości także posiada. Wymóg ten jest związany z koniecznością zebrania obiektywnego materiału dowodowego. Dokonanie arbitralnych ustaleń przez właściwe organy czy sądy w oparciu na podstawie wiedzy własnej mogłoby się spotkać z uzasadnioną krytyką co do rzetelności postępowania.

Wiedza specjalistyczna biegłych wykorzystywana jest w sytuacjach, kiedy zawiodła prewencja pożarowa. To prawidłowe ustalenia biegłych pozwalają na weryfikację standardów bezpieczeństwa pożarowego w szerokiej perspektywie.

$\mathrm{Na}$ etapie ustalania przyczyn pożarów biegli najczęściej występują w związku prowadzonym postępowaniem karnym. Są powoływani także w procesach cywilnych np. związanych z odszkodowaniami. Wtedy mając na względzie, że zgodnie z ogólnymi warunkami ubezpieczenia ubezpieczony zobowiązany jest do przestrzegania powszechnie obowiązujących przepisów [w tym przepisów prawa budowlanego, ochrony przeciwpożarowej, eksploatacji i konserwacji budynków i budowli, budowy i eksploatacji urządzeń technicznych, wykonywania dozoru technicznego nad urządzeniami oraz wykonywania zobowiązań wymienionych w umowie ubezpieczenia (por. [12]), opiniują, czy wymienione wymogi zostały spełnione. 
Legal doctrine contains the following statement: "Fires are events in which evidence is extremely difficult to gather. To determine the place and the causes of fire occurrence and spread, it is necessary to engage a specialist - a firefighting (fire protection) expert" [13]. It is worth noting that this statement is a simplification towards an informal language. In the penal process, there is a marked distinction between specialists (i.e. persons usually having technical knowledge, employed with or serving law enforcement agencies, and performing technical operations which include in particular performing measurements or calculations, taking photos and recording evidence) and expert witnesses (i.e. persons having specialised knowledge and appointed for the purpose of issuing informed opinions). The postulate to formally institute the position of a consultant - a person providing the necessary assistance to the judicial body in the procedures requiring specialised knowledge - as proposed by B. Skiba, has been recognised in legal doctrine [14, p. 15].

T. Sawicki has noted that "in our country there are neither clear-cut procedures for conducting fire investigations nor a system of training "experts" to professionally determine the causes of fires" [15, p. 28]. This opinion, if considered accurate, does not imply that this is not advisable.

As stressed by B. Szerszenowicz, a reliable identification of the cause of a fire requires an expert witness to perform his/her work adequately. In criminal proceedings, the expert witness's opinion should contain no statements regarding guilt [16, p. 67] of the accused party or any legal assessments of that party's actions [17], as the power to determine these issues fully rests with the court [18] (this also concerns, inter alia, determining whether an attempt has been made to cause the fire, as defined in the Civil Code [19]). Moreover, W. Karasiński has noted that such an opinion can also contain some general conclusions, wider than those required as part of the expert opinion, and regarding, inter alia, the preventive measures taken within a plant, the provision of specialised equipment, or firefighting units, etc. [20].

Questions addressed to the expert witness cannot, at any rate, go beyond the competencies determined by his/her specialised knowledge [18, p. 22]. If the expert witness also takes into consideration other evidentiary material or data, which he/ she has previously had access to in connection with acting as expert witness, this should be mentioned in the opinion [19, p. 10]. The concluding part should contain responses to the questions made by the judicial body [20, p. 8]. A. Koniuch and D. Małozięć have pointed out that the questions addressed to expert witnesses should refer to their firefighting expertise and allow the court to determine, on the basis of their responses, whether the criteria of a prohibited act have been fulfilled. Nonetheless, expert witnesses' opinions on firefighting issues must not contain any direct statements on the fulfilment of these criteria [24].

In the case of significant discrepancies, the authority commissioning expert witnesses is allowed to evaluate the arguments presented by two witnesses and the conclusions formulated through their confrontation [19, p. 10].

Given that it is not the expert witness's role to determine the actual status of the case (as responsibility for this rests with the judicial body), the methods of conducting criminal proceedings
W doktrynie odnaleźć można takie sformułowanie: „Pożary należą do tych zdarzeń, $w$ których postępowanie dowodowe jest bardzo trudne. Do ustalenia miejsca, przyczyny powstania i rozprzestrzeniania się pożaru itp. potrzeba specjalisty - biegłego z zakresu pożarnictwa (ochrony przeciwpożarowej)" [13]. Wyjaśnić trzeba, że jest to pewne uproszczenie podążające w stronę języka potocznego. W procesie karnym występuje wyraźne odróżnienie specjalistów (czyli osób mających najczęściej wiedzę techniczną, będących pracownikami albo funkcjonariuszami organów ścigania i wykonujących czynności techniczne, w szczególności takie jak wykonanie pomiarów, obliczeń, zdjęć, utrwalenie śladów) od biegłych (czyli osób mających wiadomości specjalne, powoływanych do wydania opinii). W doktrynie pojawił się, zaprezentowany przez B. Skibę, postulat formalnego powołania instytucji konsultanta (uregulowania jej w procedurze karnej) - osoby, która udziela organowi procesowemu niezbędnej pomocy w czynnościach, wymagających wiedzy specjalistycznej [14, s. 15].

T. Sawicki wskazał, że „w naszym kraju nie ma zarówno opracowanych procedur prowadzenia dochodzeń popożarowych, jak i systemu przygotowania "ekspertów" do profesjonalnego ustalania przyczyn powstawania pożarów" [15, s. 28]. Pogląd ten - jeżeli jest prawdziwy - nie oznacza, że stan taki nie jest celowy.

Jak akcentował B. Szerszenowicz, tylko prawidłowo wykonana praca biegłego pozwala na wiarygodne określenie przyczyn pożarów. W odniesieniu do procedury karnej opinia biegłego nie powinna zawierać sformułowań dotyczących winy [16, s. 67] oskarżonego lub oceny prawnej jego czynu [17], ponieważ uprawnienia w tym zakresie lezą wyłącznie po stronie sądu [18] (podobnie jak - przykładowo - ustalenie, czy miało miejsce usiłowanie sprowadzenia pożaru w rozumieniu Kodeksu karnego [19]). Ponadto W. Karasiński zauważył, że opinia może zawierać wnioski natury ogólnej, szersze niż wynika to z ram ekspertyzy, np. dotyczące zabezpieczenia prewencyjnego zakładu, wyposażenia specjalistycznego obiektów i jednostek straży pożarnych itp. [20].

W żadnym przypadku pytania kierowane do biegłego nie mogą wychodzić poza kompetencje określone jego specjalnymi wiadomościami [18, s. 22]. Jeżeli biegły uwzględnia również inne materiały dowodowe albo dane znane mu z jego działalności w charakterze biegłego, wówczas należy zaznaczyć to w opinii [19, s. 10]. Część końcowa powinna zawierać odpowiedzi na pytania postawione przez organ procesowy [20, s. 8]. A. Koniuch i D. Małozięć wskazali, że pytania zadawane biegłym powinny dotyczyć wiedzy fachowej z zakresu pożarnictwa i być precyzowane w sposób umożliwiający sądom podjęcie decyzji, czy znamiona czynu zabronionego zostały wypełnione. Opinie biegłych z zakresu pożarnictwa nie powinny zawierać stwierdzeń dotyczących wypełnienia przedmiotowych znamion [24].

W przypadku istotnych rozbieżności organ zarządzający przeprowadzenie badania może poddać ocenie argumenty tych dwóch biegłych i wnioski wynikające z konfrontacji biegłych [19, s. 10].

Skoro rolą biegłego nie jest ustalanie stanu faktycznego sprawy (bo to wyłączna domena podmiotu prowadzącego postępowanie), to i metodyka postępowania karnego nie zależy od biegłego, który występuje wyłącznie na określonym etapie tegoż postępowania, nie jest jego gospodarzem i wykonuje je- 
are also beyond the expert witness's control, since the expert's actions take place only at a given stage of the proceedings and are limited to the commissioned tasks. In addition, A. Krachało has stressed that expert witnesses can use the assistance of other people as regards technical and support activities [22, s. 51].

Nonetheless, it is far from true that there is no specific methodology of conducting criminal proceedings.

The procedural acts performed by using the knowledge of tactics and forensic techniques, as well as methodologies of conducting evidentiary proceedings in the cases relating to selected crimes, form part of the prosecutor apprenticeship programme (see Annex to Regulation No. 27/2014 of the Programme Council of the National School of the Judiciary and Prosecution Service).

Indeed, there is no official system of preparing expert witnesses for the professional identification of the causes of fires. Nor is there any system of preparing them for determining the cases of road accidents. However, there is some literature [26] as regards issuing opinions [23, p. 12]. What appears particularly important is having specialised knowledge and not how it has been acquired - as long as the knowledge that is shared is of high quality, there are no restrictions concerning its acquisition, whether at (postgraduate) studies or courses. A scientist, an exceptional theoretician in the given field, a State Fire Service officer with the adequate professional experience, and a fire protection appraiser having the adequate specialised knowledge - they can all be equally good expert witnesses. While there is no justified doubt as to the level of fire safety education, the methods of identifying the causes of fires may raise certain objections.

The fact that very specific and high requirements are imposed on expert witnesses (other than the currently required submission of documents to the chairperson of the relevant district court, proving the expert witness' competencies, e.g. participation in several scientific conferences) appears justified in the light of the responsibility they are expected to assume. While performing their expert witness duties, they must show impartiality and knowledge, as these are the indispensable conditions for properly conducting the process and determining the objective truth [19, p. 10]. The mistakes that sometimes happen are caused by the lack of sufficient knowledge or diligence, and also by relying on sources other than legal acts (e.g. public opinion) [19, p. 10].

P. Guzewski, D. Wróblewski and D. Małozięć have pointed out that "it also ought to be borne in mind that the suggested necessity for implementing changes in the field of fire investigation in Poland results not only from the reasonable needs and social rights guaranteed in the Constitution (the right to safety) but also from the need to adapt to the advances in fire investigation and the standards of identifying the causes of fires, binding in the European Union" [27].

\section{Identifying the causes of fires}

Identifying the causes of fires is "a natural element of fire protection, the principal purpose of which is to protect human life, health, property and the environment. Research on fires dynie czynności zlecone. Dodatkowo A. Krachało podkreśla, że biegłemu wolno korzystać z pomocy innych osób jako swych pomocników w zakresie czynności technicznych i pomocniczych [22, s. 51].

Nie jest natomiast prawdą, że nie ma stosownej metodyki prowadzenia postępowań karnych.

Czynności procesowe realizowane z wykorzystaniem wiedzy z zakresu taktyki i techniki kryminalistycznej oraz metodyka postępowania dowodowego w sprawach o wybrane przestępstwa to element programu aplikacji prokuratorskiej (por. Załącznik do uchwały nr 27/2014 Rady Programowej KSSiP).

Istotnie nie ma urzędowego systemu przygotowywania biegłych do profesjonalnego ustalania przyczyn powstawania pożarów, podobnie jak brakuje go do ustalania przyczyn wypadków drogowych. Jednakże dostępna jest liczna literatura fachowa [26] dotycząca opiniowana [23, s. 12]. Znaczenie ma posiadanie wiadomości specjalnych, a nie sposób ich pozyskania - o ile przekazywana wiedza zawiera wysokie wartości merytoryczne, nie ma przeszkód do jej pozyskania np. w ramach kursu czy studiów (podyplomowych). Równie dobrym biegłym może być naukowiec, wybitny teoretyk ze swojej dziedziny, funkcjonariusz PSP z odpowiednim doświadczeniem zawodowym, jak i rzeczoznawca do spraw zabezpieczeń przeciwpożarowych posiadający odpowiednie wiadomości specjalne. Nie zachodzi uzasadniona obawa o poziom kształcenia w zakresie bezpieczeństwa pożarowego, natomiast zastrzeżenia może budzić metodyka ustalania przyczyn pożarów.

Stawianie biegłym konkretnych, wysokich wymagań (innych niż obowiązujące obecnie formalne przedstawienie dokumentów prezesowi właściwego sądu okręgowego wskazujących na kompetencje do bycia biegłym np. poprzez uczestnictwo w kilku konferencjach naukowych) uzasadnione jest spoczywającą na nich odpowiedzialnością. W swojej pracy muszą kierować się obiektywizmem i wiedzą - jest to niezbędny warunek prawidłowego przebiegu procesu i ustalenia prawdy materialnej [19, s. 10]. Zdarzające się pomyłki spowodowane są brakiem wiedzy lub solidności, a także sugerowaniem się źródłami poza aktami prawnymi (np. opinią publiczną) [19, s. 10].

P. Guzewski, D. Wróblewski i D. Małozięć wskazali, że „należy też mieć na uwadze, że formułowana konieczność przeprowadzenia zmian w obszarze dochodzeń popożarowych w Polsce wynika nie tylko z uzasadnionych potrzeb i praw społecznych gwarantowanych konstytucyjnie (prawo do bezpieczeństwa), ale również z konieczności dostosowania się do kierunków rozwoju dochodzeń popożarowych oraz standardów ustalania przyczyn pożarów w Unii Europejskiej" [27].

\section{Ustalanie przyczyn pożarów}

Ustalanie przyczyn pożarów jest „naturalnym elementem ochrony przeciwpożarowej, której nadrzędnym celem jest ochrona życia, zdrowia, mienia lub środowiska. Badania prowa- 
and their causes constitutes a form of acquiring the cognitive material necessary for the proper formulation of the State's internal safety policy" [15, p. 25]. In addition, the knowledge so acquired contributes to updating and developing the expertise in this field. By analysing real-life cases, it is also possible to verify the results of theoretical studies or those obtained under laboratory conditions.

According to S. Machowicz, fire investigations "are procedures conducted in connection with the occurrence of a fire or a vapour cloud explosion. In Poland, the causes of fires are identified by various entities, including law enforcement bodies, the judiciary, and insurance market actors" [25, p. 51 et sec.]. This multitude of entities reflects the necessity for training professionals whose knowledge will make it possible to identify the causes of fires.

It is advocated that "criminal proceedings in cases related to causing a fire, as a generally dangerous event, are considered among the most complicated when it comes to evidence. This results from the fact that in such cases the investigation bodies can be left with little evidentiary material, while the initial - and extremely important for the overall effectiveness of the proceedings - measures are taken by the competent authorities right after the firefighters and other services taking part in the extinguishing and rescue operation complete their tasks" [23, p. 12].

It is not until the fire is extinguished that its actual cause can be identified, and only then can we determine, inter alia, whether we are dealing with arson, which is a criminal act, or whether any gross negligence has occurred as regards compliance with the applicable law, including fire protection regulations. "A set of actions performed during investigations provides the source of information on the course of the fire and its characteristics, serving the purpose of determining the circumstances, and the quality and quantity of burned-down property. Witnesses' testimony, the site of the fire origin, fire duration, the colour of smoke, wind direction, etc., all constitute extremely important elements" [1, p. 221]. The gathering of the complete analytical material is of primary importance for the correctness of the obtained results, while it is also worth noting that some of the activities cannot be done twice. Improperly conducted or poorly documented investigation can thwart the opinion-making process or provide grounds for the opinion's being challenged during evidence assessment. In addition, when determining the site of the fire origin, "members of the investigation team should rely on the various information gathered during the preliminary investigation, i.e. data obtained from firefighters, their own findings, and any testimony given by the injured parties or witnesses. This initially acquired knowledge should be then verified on the basis of the trace evidence revealed in the course of the detailed investigation of the site of the fire" [25, p. 51]. What is particularly important here is witnesses' testimony [23, p. 15].

"Prior to investigating the site of a fire, it is indispensable for the State Fire Service officers to take the appropriate steps to secure the site, prepare passageways, enable access to the seat of the fire and other objects, etc." [25, p. 51]. This observation is of a purely technical nature, illustrating the principles of moving around the site in a manner balancing the need to both collect evidence and maintain the safety at the site of the investigation. dzone nad pożarami i ich przyczynami stanowią jedną z form uzyskiwania materiału poznawczego, niezbędnego dla określenia prawidłowej polityki państwa w zakresie bezpieczeństwa wewnętrznego" [15, s. 25]. Co więcej, pozyskana w ten sposób wiedza wpływa na aktualizację i rozwój stanu nauki w omawianym zakresie. Badania konkretnych przypadków pozwalają też na weryfikację wyników badań teoretycznych oraz uzyskiwanych w warunkach laboratoryjnych.

Dochodzenia popożarowe - jak pisze S. Machowicz - „są to postępowania prowadzone w związku z zaistnieniem zjawiska pożaru lub wybuchu przestrzennego. W Polsce ustalaniem przyczyn pożarów zajmują się różne podmioty. Są to organy ścigania, wymiaru sprawiedliwości czy też uczestnicy rynku ubezpieczeniowego" [25, s. 51 i in.]. Wskazywana wielość podmiotów obrazuje istnienie potrzeb w zakresie kształcenia profesjonalistów, których wiedza będzie pozwalała na określenie przyczyn pożarów.

Jak się podnosi „postępowania karne, których przedmiotem jest sprowadzenie pożaru jako zdarzenia powszechnie niebezpiecznego uznawane są za jedne z najbardziej skomplikowanych pod względem dowodowym. Wynika to $z$ faktu, że w tego typu sprawach organy śledcze mogą dysponować niewielką ilością materiału dowodowego, natomiast pierwsze - niezwykle istotne dla efektywności postępowania - czynności, organy procesowe dokonują tuż po zakończeniu przez funkcjonariuszy straży pożarnej i innych służb akcji gaśniczej i ratunkowej" [23, s. 12].

Dopiero po ugaszeniu pożaru jest możliwe wyjaśnienie rzeczywistej przyczyny jego powstania, m.in. ustalenie, czy mamy do czynienia ze zbrodniczym podpaleniem, czy nie doszło do rażących zaniedbań w zakresie przestrzegania przepisów związanych np. z ochroną przeciwpożarową. „Zbiór czynności wykonywanych w wyniku oględzin stanowi źródło informacji o przebiegu pożaru, jego cechach, służy ustaleniu okoliczności, określeniu ilości i jakości spalonego mienia. Bardzo ważny element stanowią zeznania świadków, miejsce powstania pożaru, czas, kolor dymu, kierunek wiatrów itp." [1, s. 221]. Prawidłowe ustalenie pełnego materiału badawczego ma istotne znaczenie dla poprawności uzyskiwanych wyników, a trzeba mieć na uwadze, że części czynności nie da się powtórzyć. Nieprawidłowo wykonane albo źle udokumentowane oględziny mogą wypaczyć możliwość wydania prawidłowej opinii albo ułatwić jej podważenie w procesie oceny dowodów. Uzupełnieniem powyższego stanowiska jest ocena, że lokalizując miejsce powstania pożaru, „członkowie grupy oględzinowej powinni opierać się na licznych informacjach zgromadzonych $w$ trakcie oględzin wstępnych, a więc m.in. na danych uzyskanych od funkcjonariuszy straży pożarnej, własnych spostrzeżeniach, zeznaniach osób poszkodowanych bądź świadków. Wstępnie uzyskana wiedza powinna być następnie zweryfikowana na podstawie śladów kryminalistycznych ujawnionych w czasie prowadzenia oględzin szczegółowych miejsca pożaru" [25, s. 51]. Szczególnie podkreśla się, że istotne są zeznania świadków [23, s. 15].

„Przed przystąpieniem do przeprowadzenia badania pogorzeliska koniecznym jest, aby funkcjonariusze Państwowej Straży Pożarnej poczynili odpowiednie zmiany w celu zabezpieczenia terenu, wykonali przejścia, umożliwili dostęp do ogniska pożaru i innych obiektów itp." [25, s. 51]. Jest to spostrzeżenie czysto 
B. Ościłowska has argued that documentation regarding the site of the event, as drawn up by the person in charge of the rescue operation, can also be the source of evidentiary material [28].

\section{Summary}

P. Guzewski has pointed out that "the scientific development of the studies of the causes of fires could not begin until modern times, and it was fostered by the flourishing of exact and natural sciences in the 19th and 20th centuries. The application of scientific knowledge in fire investigations has been actually practised only since the second half of the 20th century. This was when a belief was developed that the identification and analysis of the causes of fires could form an essential element of fire prevention. Since then, detailed analyses of the nature of fire have been conducted, and fire prevention programmes and technologies have been implemented. This made it possible to take informed prevention measures, in material, technological, structural, organisational and social terms. The flourishing of exact sciences and the technological advancements in the 20th century contributed in particular to improved safety standards and found practical application in facilitating the process of identifying the causes of fires" [9, pp. 905-906].

Undoubtedly, the activities and knowledge of expert witnesses are essential for fire safety. Only people with considerable specialised knowledge can materially support the operations of law enforcement bodies and contribute to the correct assessment of fire-related events.

As claimed by K. Karwowska and A. Gawliński, clarifying the circumstances of a fire is "a rather challenging task" from the forensic point of view. Initially, attempts are made to determine the factors that caused a fire, and those that contributed to its spreading [29]. The average degree of detectability of the cause of a fire is $30-38 \%$. It is also worth noting that the analysis of such causes, as presented by S. Wieteska, has shown that women and retirees are responsible for a large number of arson cases [1, p. 218]. According to P. Piotrowski, the conducted research has also revealed that the arsonists, as compared to other criminals, show an increased interest in fire, persistently view the setting of fire as a "normal" behaviour, and display a reduced awareness of fire safety. In addition, they are characterised by generally low self-esteem, hostility and inclination to rumination, along with an increased tendency to respond with anger when provoked [30]. These findings should provide material for further studies and reviews, which may ultimately prove useful in determining the causes of fires.

One should also not forget that the activities of fire-safety expert witnesses are burdened with some shortcomings, including the lack of established methodology and working methods. Obviously, these not only concern fire-safety expert witnesses. Nonetheless, it appears justified to undertake a dis- techniczne, obrazujące zasady poruszania się po pogorzelisku tak aby zrównoważyć potrzebę zebrania materiału dowodowego i konieczność zachowania bezpieczeństwa w miejscu przeprowadzania oględzin.

B. Ościłowska zauważa, że źródłem materiału dowodowego może być także dokumentacja dotycząca miejsca zdarzenia wykonywana przez kierującego działaniem ratowniczym (KDR) [28].

\section{Podsumowanie}

P. Guzewski wskazuje, że „rozwój naukowy badań przyczyn pożarów możliwy był dopiero $w$ czasach nam współczesnych wraz z rozwojem nauk ścisłych i przyrodniczych w XIX i XX w. Zastosowanie podstaw naukowych $w$ dochodzeniach popożarowych miało miejsce tak naprawdę dopiero $w 2$. poł. XX w., gdy zrozumiano, że istotnym elementem profilaktyki pożarowej może być identyfikacja oraz analiza przyczyn pożarów. Od tego czasu zaczęto szczegółowo badać naturę ognia, analizować okoliczności powstawania pożarów, wdrażać technologie oraz programy zapobiegające ich powstawaniu. Pozwoliło to po raz pierwszy na wprowadzanie świadomych oddziaływań profilaktycznych zarówno w aspektach materiałowym, technologicznym, konstrukcyjnym, jak i organizacyjnym oraz społecznym. Rozwój nauk ścisłych i rozwój technologiczny w XX w. w sposób szczególny przyczyniły się do poprawy standardów bezpieczeństwa oraz znalazły praktyczne zastosowanie w usprawnieniu procesu ustalania przyczyn pożarów" [9, s. 905-906].

Niewątpliwie działalność biegłych oraz ich wiedza odgrywają wiodącą rolę w zakresie bezpieczeństwa pożarowego. Wyłącznie osoby o wysokiej wiedzy specjalistycznej mogą istotnie wesprzeć działalność organów ścigania i przyczynić się do prawidłowej oceny zdarzeń związanych z pożarami.

Jak wskazali K. Karwowska i A. Gawliński, wyjaśnienie okoliczności pożaru „to dość ciężkie zadanie” z punktu widzenia kryminalistyki. Początkowo dąży się do ustalenia czynników, które pożar spowodowały oraz tych, które sprzyjały jego rozprzestrzenianiu [29]. Przeciętny stopień wykrywalności przyczyny pożaru wynosi 30-38\%. Na marginesie można wspomnieć, że analiza przyczyn pożarów - przytoczona przez S. Wieteskę - wskazuje na wysoką liczbę podpaleń dokonywanych przez kobiety i emerytów [1, s. 218]. Według P. Piotrowskiego z przeprowadzonych badań wynikło także, że sprawcy podpaleń, w porównaniu do innych przestępców, wykazywali większe zainteresowanie ogniem, mieli utrwalone postawy legitymizujące podpalenie jako "normalny" sposób postępowania oraz przejawiali mniejszą świadomość w zakresie bezpieczeństwa pożarowego. Poza tym podpalacze charakteryzowali się niską samooceną ogólną, większą wrogością i skłonnością do ruminacji, a także większą tendencją do reagowania gniewem w odpowiedzi na prowokację [30]. Spostrzeżenia te powinny stanowić materiał do dalszych badań i weryfikacji, który finalnie może być pomocny w ustalaniu przyczyn pożarów.

Nie można tracić z pola widzenia tego, że działalność biegłych z zakresu pożarnictwa obarczona jest pewnymi niedostatkami, jak np. brakiem ustalonej metodologii i metodyki pracy. Oczywiście nie jest to przypadłość dotycząca wyłącznie bie- 
cussion on the desirable level of their qualifications, and on the limits of their powers and competencies, as exercised in the work commissioned by law enforcement bodies and insurance companies. Perhaps such a discussion could cover both the rights vested in expert witnesses and the indication of the potentially most suitable moment for their specialised knowledge to be used.

\section{Literature / Literatura}

[1] Wieteska S., Zjawisko podpaleń w Polsce jako element ryzyka w działalności gospodarczej, „Annales. Etyka w Życiu Gospodarczym”, 2013, 16, 215-225.

[2] Pachnik K., Zapewnienie bezpieczeństwa w budynkach użyteczności publicznej waspekcie wykrywania izwalczania przestępstw o charakterze terrorystycznym., w: Bezpieczeństwo antyterrorystyczne budynków użyteczności publicznej. Analiza-diagnoza-case study, B. Wiśniewska-Paź, M. Szostak, i J. Stelmach (red.), Toruń 2018.

[3] Wolanin M., Zasadnicze problemy dopuszczalności ustalenia i pobrania opłaty planistycznej oraz jej zwrotu, cz. V - naliczanie i pobieranie opłaty planistycznej, „Nieruchomości” 2012, nr 1.

[4] Janik P., Rola i zadania prewencji pożarowej, w: Czerwona księga pożarów Wybrane problemy pożarów oraz ich skutków, t. II, P. Guzewski, D. Wróblewski, i D. Małozięć (red), CNBOP-PIB, Józefów 2016.

[5] Witczak D., Pojęcie pożaru w świetle obowiązujących przepisów prawnych, nauki prawa i orzecznictwa, "Zeszyty Naukowe SGSP” 2015, nr 1.

[6] Pachnik K., Podmioty wydające opinie z wykorzystaniem wiadomości specjalnych w prawie polskim, „Problemy Kryminalistyki” 2015, t. 290.

[7] Wyrok Naczelnego Sądu Administracyjnego z dnia 17 lipca 2012 r., sygn. akt II GSK 969/11.

[8] Wyrok Naczelnego Sądu Administracyjnego, z dnia 23 maja 2017 r., sygn. akt II GSK 2424/15

[9] Guzewski P., Metody i środki w ustalaniu źródła oraz przyczyny pożaru", w: Czerwona Księga Pożarów. Wybrane problemy pożarów oraz ich skutków, P. Guzewski, D. Wróblewski, i D. Małozięć (red.), CNBOP-PIB, Józefów 2014.

[10] Pachnik K., Biegli w praktyce sądowej, Siedlce 2015.

[11] Wyrok Wojewódzkiego Sądu Administracyjnego siedziba w Warszawie, z dnia 3 grudnia 2008 r., sygn. akt VII SA/Wa 811/08.

[12] Wyrok Sądu Apelacyjnego w Łodzi - I Wydział Cywilny, z dnia 30 stycznia 2018 r., sygn. akt I ACa 721/17

[13] Sawicki T., Opinia biegłego sądowego z zakresu pożarnictwa - kim jest biegły sądowy, jaką wagę ma jego opinia, odpowiedzialność biegłego oraz zasady formułowania opinii $i$ ich negatywne przykłady, „Przegląd Pożarniczy", 2015, 8.

[14] Skiba B., Wykorzystywanie opinii biegłych w sprawach o zbrodnicze podpalenia, „Przegląd Pożarniczy” 1983, 6. głych z zakresu pożarnictwa. Niemniej z pewnością zasadne wydaje się podjęcie dyskusji o pożądanym poziomie kwalifikacji biegłych z zakresu pożarnictwa, jak również o granicach ich uprawnień i kompetencji w pracach dla organów ścigania i towarzystw ubezpieczeniowych. Być może zakresem dyskusji można objąć zarówno uprawnienia biegłych, jak i ustalenie potencjalnie najwłaściwszego momentu dla wykorzystania ich wiadomości specjalnych.

[15] Sawicki T., Dochodzenia popożarowe - niedoceniana szansa na poprawę bezpieczeństwa, BiTP Vol. 23 Issue 2, 2011, pp. 25-30.

[16] Szerszenowicz B., Dowód z opinii biegłego w orzecznictwie Sądu Najwyższego, "Wojskowy Przegląd Prawniczy” 1988, nr 1.

[17] Wyrok Sądu Najwyższego, z dnia 27 września 1958 r., sygn. akt III KRN $1261 / 57$.

[18] Wyrok Sądu Najwyższego, z dnia 3 lipca 1987 r., sygn. akt III KR 235/87.

[19] Postanowienie Sądu Apelacyjnego w Krakowie, z dnia 8 grudnia 1993 r., sygn. akt II Akz 355/93.

[20] Kasiński W., Udział biegłych w sprawach o podpalenia, „Przegląd Pożarniczy",1982, nr 8.

[21] Terlikowski T., Cele i zadania ekspertyzy w sprawach karnych o pożary, "Zeszyty Naukowe SGSP", 1990, nr 1.

[22] Krachało A., Funkcjonariusz pożarnictwa jako biegły, „Przegląd Pożarniczy", 1980, nr 7 .

[23] Terlikowski T., Struktura opinii biegłego występującego w sprawach karnych o pożary, „Zeszyty Naukowe SGSP”, 1991, nr 1.

[24] Koniuch A., Małozięć D., Art. 163 Kodeksu karnego w opiniach biegłych z zakresu pożarnictwa, Bezpieczeństwo Technika Pożarnicza, nr 1, 2008.

[25] Machowicz S., Rozważania wokół biegłego, „Przegląd Pożarniczy”, 1999, $\mathrm{nr} 10$.

[26] Wąsik N., Sygit B., Wartość dowodowa zeznań świadków w sprawach karnych o pożary, „Prokur. Prawo”, nr 2017, 12.

[27] Guzewski P., Wróblewski D., Małozięć D., (red.), Czerwona Księga Pożarów. Wybrane problemy pożarów oraz ich skutków., t. l., Józefów 2016.

[28] Ościłowska B., Organizacja dochodzeń popożarowych w Polsce, w: Czerwona Księga Pożarów. Wybrane problemy pożarów oraz ich skutków., P. Guzewski, D. Wróblewski, D. Małozięć (red.), Józefów 2014

[29] Karwowska K., Gawliński A., Kryminalistyczne i sądowo-lekarskie aspekty badania zwłok ofiar pożarów, „Stud. Zeszyty Naukowe”, 2015, t. 27 https://doi.org/10.17951/szn.2015.18.27.28.

[30] Piotrowski P., Sprawcy podpalenia - charakterystyka psychologiczna, BiTP Vol. 45 Issue 1, 2017, pp. 88-100, https://doi.org/10.12845/ bitp.45.1.2017. 
KAROL PACHNIK, PH.D. - Doctor of Legal Science; Associate Professor at the Faculty of Economic and Legal Sciences, the Siedlce University of Natural Sciences and Humanities, and academic teacher, inter alia, at the University of Warsaw and the War Studies University. Barrister, member of the Bar Association in Warsaw, and Disciplinary Court judge at the Bar Association in Warsaw. Expert of the W. Bayer Bar Research Centre during the term of office 2013-2016. Member of the Barrister Training Commission established within the Supreme Bar Council, during the term of office 2013-2016, member of the Barrister Training Commission established within the District Bar Council in Warsaw, and member of the Youth Association established within the District Bar Council in Warsaw. Chairman of the Administrative Law, and Case and Administrative Law Section established within the District Bar Council in Warsaw. Representative of the President of the Supreme Bar Council for legislation. Lecturer in barrister apprenticeship programmes and professional training programmes for barristers, and examiner during barrister examination in commissions appointed by the Minister of Justice. Reviewer of the Młoda Palestra magazine, Scientific Papers of the War Studies University, and the Problemy Kryminalistyki quarterly. He has appeared as a proxy before the Supreme Court, the Supreme Administrative Court and the Constitutional Tribunal. Member of the Polish Forensic Association and the Association for the Economic Analysis of Law.
DR KAROL PACHNIK - doktor nauk prawnych. Adiunkt na Wydziale Nauk Ekonomicznych i Prawnych Uniwersytetu Przyrodniczo-Humanistycznego w Siedlcach, wykładowca akademicki m.in. Uniwersytetu Warszawskiego i Akademii Sztuki Wojennej. Adwokat, członek Izby Adwokackiej w Warszawie, sędzia Sądu Dyscyplinarnego Izby Adwokackiej w Warszawie. Ekspert Ośrodka Badawczego Adwokatury im. adw. W. Bayera kadencji 2013-2016. Członek Komisji Inicjatyw Młodych Adwokatów przy NRA kadencji 2013-2016, członek Komisji Szkolenia Aplikantów Adwokackich Okręgowej Rady Adwokackiej w Warszawie i Koła Młodych przy ORA w Warszawie. Przewodniczący Sekcji Prawa Administracyjnego i Sądowo-Administracyjnego Okręgowej Rady Adwokackiej w Warszawie. Pełnomocnik Prezesa Naczelnej Rady Adwokackiej ds. legislacji. Wykładowca na aplikacji adwokackiej i w ramach wykładów doskonalenia zawodowego adwokatów oraz egzaminator na adwokackim egzaminie zawodowym w komisjach powoływanych przez Ministra Sprawiedliwości. Recenzent w czasopismach "Młoda Palestra”, "Zeszyty Naukowe Akademii Sztuki Wojennej” i „Problemy Kryminalistyki”. Jako pełnomocnik występował przed Sądem Najwyższym, Naczelnym Sądem Administracyjnym i Trybunałem Konstytucyjnym. Członek Polskiego Towarzystwa Kryminalistycznego i Stowarzyszenia Ekonomicznej Analizy Prawa. Ministerstwo Nauki
iSzkolnictwa Wyższego i Szkolnictwa Wyższego

Stworzenie anglojęzycznych wersji oryginalnych artykułów naukowych wydawanych w kwartalniku „BITP. Bezpieczeństwo i Technika Pożarnicza" - zadanie finansowane w ramach umowy 658/P-DUN/2018 ze środków Ministra Nauki i Szkolnictwa Wyższego przeznaczonych na działalność upowszechniającą naukę. 